\title{
Anomalous distribution of distinctive water masses over the Carlsberg Ridge in May 2012
}

\author{
Hailun He${ }^{1}$, Yuan Wang ${ }^{2}$, Xiqiu Han ${ }^{2}$, Yanzhou Wei ${ }^{1}$, Pengfei Lin ${ }^{3}$, Zhongyan Qiu $^{2}$, and Yejian Wang ${ }^{2}$ \\ ${ }^{1}$ State Key Laboratory of Satellite Ocean Environment Dynamics, Second Institute of Oceanography, \\ Ministry of Natural Resources, Hangzhou 310012, China \\ ${ }^{2}$ Key Laboratory of Submarine Geosciences, Second Institute of Oceanography, \\ Ministry of Natural Resources, Hangzhou 310012, China \\ ${ }^{3}$ State Key Laboratory of Numerical Modeling for Atmospheric Sciences and Geophysical Fluid Dynamics, \\ Institute of Atmospheric Physics, Chinese Academy of Sciences, Beijing 100029, China
}

Correspondence: Hailun He (hehailun@sio.org.cn) and Xiqiu Han (xqhan@ sio.org.cn)

Received: 4 June 2019 - Discussion started: 7 August 2019

Revised: 4 June 2020 - Accepted: 15 June 2020 - Published: 27 July 2020

\begin{abstract}
In May 2012, we conducted a hydrographic survey over the Carlsberg Ridge in the northwest Indian Ocean. In this paper, we use these station data, in combination with some free-floating Argo profiles, to obtain the sectional temperature and salinity fields, and subsequently, the hydrographic characteristics are comprehensively analyzed. Through the basic T-S diagram, three salty water masses, Arabian Sea High-Salinity Water, Persian Gulf Water, and Red Sea Water, are identified. The sectional data show a clear ventilation structure associated with Arabian Sea HighSalinity Water. The 35.8 psu salty water sinks at $6.9^{\circ} \mathrm{N}$ and extends southward to $4.4^{\circ} \mathrm{N}$ at depths around the thermocline, where the thermocline depth is in the range of 100 to $150 \mathrm{~m}$. This salty thermocline extends much further south than climatology indicates. Furthermore, the temperature and salinity data are used to compute the absolute geostrophic current over the specific section, and the results show mesoscale eddy vertical structure different from some widely used oceanic reanalysis data. We also find a westpropagating planetary wave at $6^{\circ} \mathrm{N}$, and the related features are described in terms of phase speed and horizontal and vertical structures.
\end{abstract}

\section{Introduction}

The northwest Indian Ocean (NWIO) is unique compared with the other two basin-scale oceans (Pacific and Atlantic oceans) because the dominant characteristics are monsoon driven (Schott and McCreary, 2001; Schott et al., 2009). The seasonal monsoon forces the coastal current back and forth and generates the Somali Current, which is always marked as the strongest current in the real ocean (as strong as $3.5 \mathrm{~m} \mathrm{~s}^{-1}$ ). Moreover, the monsoon is strong enough to change the pattern of basin-scale circulation. The monsoon builds up a dominant meridional current in the NWIO, changing the form of the customary zonal current (as in the Pacific and Atlantic oceans) into a meridional current. The NWIO is also famous for its role in the so-called Indian Ocean Dipole (Saji et al., 1999; Webster et al., 1999; Han et al., 2014; Chen et al., 2015), which represents the zonal gradient of sea surface temperature in the Indian Ocean. As a basin-wide signal, the Indian Ocean Dipole is closely related to the climate adjacent to the Indian Ocean ( $\mathrm{Li}$ and Han, 2015). Some studies also emphasized the distinct mesoand submesoscale air-sea interactions in the NWIO (Vecchi et al., 2004).

To date, the main water masses in the NWIO have been described by the scientific community (Sharma et al., 1978; Kumar and Prasad, 1999; Emery, 2001; Talley et al., 2011). For instance, three water masses were defined in the NWIO as Arabian Sea High-Salinity Water (ASHSW), Persian Gulf 
Water (PGW), and Red Sea Water (RSW). The formations of ASHSW, PGW, and RSW are all due to the high evaporation (Shapiro and Meschanov, 1991; Kumar and Prasad, 1999; Bower et al., 2000; Prasad et al., 2001; Prasad and Ikeda, 2002). Regarding the pathways of these water masses, the movements are not well observed, and the corresponding dynamics are not clear. Kumar and Prasad (1999) described the climatological seasonal distribution of ASHSW using in situ temperature and salinity fields. In the northern Arabian Sea, ASHSW forms in the surface during winter and moves southward due to the surface wind. Otherwise, the multiscale variations in ASHSW were not sufficiently documented (Kumar and Prasad, 1999; Prasad and Ikeda, 2002). According to the customary ocean ventilation theory, ASHSW sinks and moves southward along the isopycnal layer from the generation zone following the wind-driven current (Luyten et al., 1983). However, the applicability of the ocean ventilation theory is still unknown for the NWIO, because the surface wind reverses direction under the influence of winter monsoon (Liu et al., 2018). RSW supplies an important intermediate water salinity source for the entire Indian Ocean basin (Han and McCreary, 2001). Formation and spreading of RSW exhibit seasonal variations (Bower et al., 2000; Beal et al., 2000). Based on the long-term hydrographic data, the occurrence of RSW shows four possible branches of RSW around the Gulf of Aden: the first spreads southward along the Somali coast; the second moves southward to the Somali Basin; the third flows eastward to the Arabian Basin; and the fourth moves northeastward along the Arabian coast (Shapiro and Meschanov, 1991). Later, Beal et al. (2000) highlighted the branch along the Somali coast; meanwhile, potential vorticity analysis revealed that the flows generally followed the zonal direction in the NWIO. It is noted that the dynamics of intermediate water in the Indian Ocean should be different from that in the Pacific and Atlantic oceans. The limited meridional extent of the Indian Ocean omits the polarto-subpolar front, which helps forming intermediate water in Pacific and Atlantic oceans (You, 1998). How RSW moves is worthy further investigation (Durgadoo et al., 2017).

On the other hand, mesoscale eddies and planetary waves are not sufficiently observed in the NWIO. The historical and present Research Moored Array for African-AsianAustralian Monsoon Analysis and Prediction observation arrays are close to the Equator and omit the NWIO. In situ observations in the NWIO mainly depend on the Array for Real-time Geostrophic Oceanography (Argo; Riser et al., 2016; Vitale et al., 2017). However, as we show later, the number of Argo floats is still too sparse to represent the mesoscale eddy field in the NWIO. Besides, the planetary waves at least include Rossby and Kelvin waves (Rhines, 1975; McCreary, 1985). Satellite-retrieved sea surface heights are commonly used to detect the planetary waves (Chelton and Schlax, 1996), while the internal dynamics of planetary waves is not sufficiently addressed. The phase speed of west-propagating planetary waves (WPPWs) has been matched to the theoretical Rossby wave (Chelton and Schlax, 1996; Subrahmanyam et al., 2001); nonetheless, the vertical structure of WPPWs calls for vertical profiling observation (Subrahmanyam et al., 2001).

The present circumstance stimulates our effort to find more observational resources. The Carlsberg Ridge (CR) is a typical slow-spreading ridge and lies along the northwestern-southeastern direction in the NWIO. Recently, we conducted an interdisciplinary survey on the CR (Yang et al., 2016; Wang et al., 2017), and the hydrographic analysis of the CR is necessary for at least three reasons. First, hydrographic survey takes a snapshot of the water mass and gives evidence of the movement of water mass. Second, the observation probably captures the vertical structure of the mesoscale eddy or planetary wave. Third, the results could be used to evaluate widely used oceanic reanalyses. The trajectories of Argo floats are not manually controlled; however, ship surveys could cover specified sections and have a clearer objective. Hence, this paper is motivated by observing the water masses over the $\mathrm{CR}$, describing the vertical structures of mesoscale eddies and a planetary wave, and comparing the results of widely used oceanic reanalyses in the NWIO.

\section{Data and methods}

\subsection{In situ data description}

The data for our study were collected during the Chinese cruise DY125-24 (May 2012) by the Chinese research vessel LISIGUANG. Hydrographic observations were conducted in the region of the CR. The vertical profiles of temperature, conductivity and pressure were obtained by a calibrated SBE-19plus Conductivity, Temperature, and Depth (CTD) and some expendable CTDs (XCTDs). The station information is shown in Fig. 1 and Table 1. All stations were mainly located close to the $\mathrm{CR}$ section and therefore defined the regional along-section $(y)$ and cross-section $(x)$ coordinates. The XCTD and Argo maximum measurement depths are 1050 and $2000 \mathrm{~m}$, and therefore we limited our analysis to a depth of $2000 \mathrm{~m}$. According to Talley et al. (2011) and Emery (2001), an upper $2000 \mathrm{~m}$ depth covers the upper ocean (defined as $0-500 \mathrm{~m}$ ) and the intermediate-depth ocean (defined as 500-2000 m). In our postprocessing, 13 contemporary Argo profiles were found within a $200 \mathrm{~km}$ radius of the study region (Fig. 2 and Table 1).

Regarding data quality, an intercomparison between XCTD and CTD measurements was implemented in the southern tropical Indian Ocean. The XCTD station involved was located at $1.7^{\circ} \mathrm{S}, 73.8^{\circ} \mathrm{E}$ at 14:23 UTC on 4 May, and the counterpart CTD station was located at $1.4^{\circ} \mathrm{S}, 73.5^{\circ} \mathrm{E}$ after $0.5 \mathrm{~h}$ (14:58 on 4 May; distance from the XCTD station was $47.17 \mathrm{~km})$. The mean differences in the recorded in situ temperature (salinity) were $0.425^{\circ} \mathrm{C}(0.058 \mathrm{psu})$ in the upper ocean and $0.051^{\circ} \mathrm{C}(0.053 \mathrm{psu})$ in the intermediate-depth 


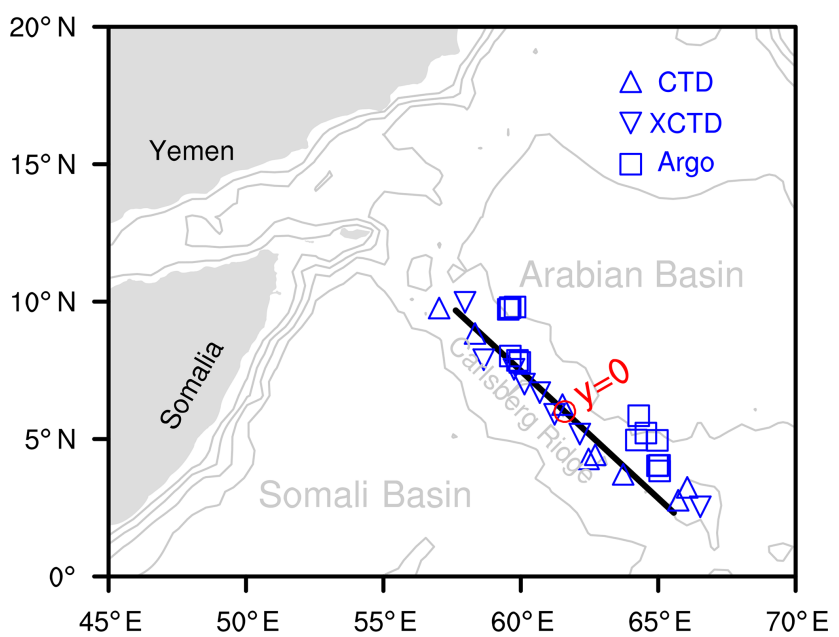

Figure 1. CTD/XCTD stations of the DY125-24 survey and the contemporary Argo profiles around the CR. The CR defines local coordinates in which the $x$ coordinate is cross track and the $y$ coordinate along track; the corresponding origin point is selected as $6.0^{\circ} \mathrm{N}, 61.6^{\circ} \mathrm{E}$, and the isobaths of $-4000,-3000,-2000$, and $-1000 \mathrm{~m}$ are presented.

ocean. It is noted that the differences among CTD and XCTD are not negligible. However, because the distance between two stations is relatively large, and the bias of XCTD is different for different instruments, we do not perform instrument calibration. We later use an objective analysis method and low-pass filter to smooth the data among CTD, XCTD, and Argo.

\subsection{In situ data processing}

All the data from several sources need to be processed to same levels because of the different sampling rates; i.e., the vertical resolutions of CTD, XCTD, and Argo are 0.1, 0.1, and $2.0 \mathrm{~m}$, respectively. In the first step of data postprocessing, the coarse data are moving-averaged into a uniform vertical grid with a $5 \mathrm{~m}$ interval starting from $5 \mathrm{~m}$ below the surface. Here $5 \mathrm{~m}$ vertical resolution is sufficient for describing vertical structure of mixed-layer and water masses. Special treatment is imposed on one Argo float (2901888; three profiles; Table 1), where the coarse profiles lose data in the upper $20 \mathrm{~m}$; thus, the missing data are filled with the same value as uppermost available data in the near surface.

The data are then projected into the standard CR section ( $y$ coordinate), and the corresponding grid interval is $50 \mathrm{~km}$. We use the objective analysis method to interpolate data from irregularly spaced locations to a fixed grid (Barnes, 1994). Later, a low-pass filter is imposed on the CR sectional data to remove the short-wavelength signals, which are partly from the cross bias among different data sources and partly from the submesoscale or higher wavenumber signals in the real ocean. The low-pass filter is a two-dimensional LOcally Estimated Scatterplot Smoothing (LOESS) filter (Cleveland
Table 1. Information on CTD/XCTD stations and Argo floats.

\begin{tabular}{lllll}
\hline Type & Station/float & Latitude & Longitude & $\begin{array}{l}\text { Time (month/ } \\
\text { day hour) }\end{array}$ \\
\hline XCTD & S09CTD08 & $2.3^{\circ} \mathrm{N}$ & $66.3^{\circ} \mathrm{E}$ & $05 / 0607$ \\
XCTD & S16CTD13 & $5.1^{\circ} \mathrm{N}$ & $62.1^{\circ} \mathrm{E}$ & $05 / 1416$ \\
XCTD & S19CTD15 & $6.4^{\circ} \mathrm{N}$ & $60.4^{\circ} \mathrm{E}$ & $05 / 1613$ \\
XCTD & S20CTD16 & $7.3^{\circ} \mathrm{N}$ & $59.5^{\circ} \mathrm{E}$ & $05 / 1619$ \\
XCTD & S23CTD19 & $7.0^{\circ} \mathrm{N}$ & $60.1^{\circ} \mathrm{E}$ & $05 / 2014$ \\
XCTD & S25CTD21 & $9.6^{\circ} \mathrm{N}$ & $57.6^{\circ} \mathrm{E}$ & $05 / 2304$ \\
XCTD & S26CTD22 & $5.5^{\circ} \mathrm{N}$ & $61.1^{\circ} \mathrm{E}$ & $05 / 2620$ \\
CTD & S10CTD09 & $3.1^{\circ} \mathrm{N}$ & $66.0^{\circ} \mathrm{E}$ & $05 / 0705$ \\
CTD & S12CTD10 & $2.5^{\circ} \mathrm{N}$ & $65.4^{\circ} \mathrm{E}$ & $05 / 0912$ \\
CTD & S14CTD11 & $4.2^{\circ} \mathrm{N}$ & $62.3^{\circ} \mathrm{E}$ & $05 / 1117$ \\
CTD & S15CTD12 & $4.3^{\circ} \mathrm{N}$ & $62.4^{\circ} \mathrm{E}$ & $05 / 1321$ \\
CTD & S17CTD14 & $6.2^{\circ} \mathrm{N}$ & $61.3^{\circ} \mathrm{E}$ & $05 / 1508$ \\
CTD & S21CTD17 & $8.5^{\circ} \mathrm{N}$ & $58.2^{\circ} \mathrm{E}$ & $05 / 1705$ \\
CTD & S22CTD18 & $9.5^{\circ} \mathrm{N}$ & $57.0^{\circ} \mathrm{E}$ & $05 / 1807$ \\
CTD & S28CTD24 & $3.4^{\circ} \mathrm{N}$ & $63.4^{\circ} \mathrm{E}$ & $06 / 0104$ \\
Argo & 2901847 & $4.0^{\circ} \mathrm{N}$ & $65.0^{\circ} \mathrm{E}$ & $05 / 0302$ \\
Argo & 2901848 & $5.8^{\circ} \mathrm{N}$ & $64.3^{\circ} \mathrm{E}$ & $05 / 0713$ \\
Argo & 2900877 & $8.0^{\circ} \mathrm{N}$ & $59.6^{\circ} \mathrm{E}$ & $05 / 0709$ \\
Argo & 2901096 & $5.0^{\circ} \mathrm{N}$ & $64.2^{\circ} \mathrm{E}$ & $05 / 0819$ \\
Argo & 2901888 & $9.7^{\circ} \mathrm{N}$ & $59.5^{\circ} \mathrm{E}$ & $05 / 0801$ \\
Argo & 2901847 & $4.0^{\circ} \mathrm{N}$ & $65.0^{\circ} \mathrm{E}$ & $05 / 1220$ \\
Argo & 2901888 & $9.8^{\circ} \mathrm{N}$ & $59.6^{\circ} \mathrm{E}$ & $05 / 1723$ \\
Argo & 2900877 & $7.9^{\circ} \mathrm{N}$ & $59.9^{\circ} \mathrm{E}$ & $05 / 1709$ \\
Argo & 2901096 & $5.2^{\circ} \mathrm{N}$ & $64.6^{\circ} \mathrm{E}$ & $05 / 1819$ \\
Argo & 2901847 & $3.8^{\circ} \mathrm{N}$ & $65.1^{\circ} \mathrm{E}$ & $05 / 2216$ \\
Argo & 2900877 & $7.8^{\circ} \mathrm{N}$ & $60.0^{\circ} \mathrm{E}$ & $05 / 2709$ \\
Argo & 2901096 & $5.0^{\circ} \mathrm{N}$ & $65.0^{\circ} \mathrm{E}$ & $05 / 2818$ \\
Argo & 2901888 & $9.8^{\circ} \mathrm{N}$ & $59.8^{\circ} \mathrm{E}$ & $05 / 2801$ \\
\hline & & & &
\end{tabular}

and Grosse, 1991), and the moving-average wavelengths are $300 \mathrm{~km}$ and $30 \mathrm{~m}$ in the horizontal and vertical directions, respectively. As a result, the smoothed data save the essential features of the thermal-salinity field but remove the noise.

\subsection{Satellite data description}

\subsubsection{Surface wind}

We use Cross-Calibrated Multi-Platform (CCMP; Atlas et al., 2011) gridded surface vector winds here (version 2.0). CCMP data are daily products, and they are projected on $0.25^{\circ} \times 0.25^{\circ}$ grids .

\subsubsection{Sea surface temperature}

The sea surface temperature (SST) data are produced by Operational Sea Surface Temperature and Sea Ice Analysis (OSTIA; Donlon et al., 2012), which merges satellite infrared and microwave products, ship, buoy, etc. OSTIA is daily product, and the horizontal resolutions are $0.05^{\circ} \times 0.05^{\circ}$. 


\subsubsection{Sea surface height}

For describing the sea surface height (SSH) and the related surface geostrophic current, we use the Archiving, Validation and Interpretation of Satellite Oceanographic (AVISO) grided data. The temporal resolution is daily, and the horizontal resolutions are $0.25^{\circ} \times 0.25^{\circ}$.

\subsection{Reanalysis data description}

As references, we also employ two widely used reanalysis datasets for comparison, aiming at evaluating the quality of reanalysis data. The first reanalysis dataset is Simple Ocean Data Assimilation (SODA, version 3.3.1; Carton and Giese, 2008; Carton et al., 2018), whose horizontal resolutions are $0.25^{\circ} \times 0.25^{\circ}$ for longitude and latitude. The second reanalysis dataset is HYbrid Coordinate Ocean Model (HYCOM, version GOPS3.0:HYCOM+NCODA global 1/12 ${ }^{\circ}$ Reanalysis GLBu0.08/expt_19.1), and its horizontal resolutions are $0.08^{\circ} \times 0.08^{\circ}$. Both SODA and HYCOM assimilate various in situ and satellite-based data sources: historical station profiles, Argo profiles, moorings, drifters, satellite SSTs, SSHs, etc. For comparison, we extract the reanalysis datasets along the same section as the observations, and the monthly mean fields in May 2012 are used.

\subsection{Method of tracers}

Using SODA reanalysis, we release some passive tracers along the CR and backtrack their trajectories based on the Lagrangian description, and the methods are formulated by

$\left\{\begin{array}{l}X^{n-1 / 2}=X^{n+1 / 2}-U^{n} \cdot \Delta t \\ Y^{n-1 / 2}=Y^{n+1 / 2}-V^{n} \cdot \Delta t \\ z^{n-1 / 2}=z^{n+1 / 2}-w^{n} \cdot \Delta t .\end{array}\right.$

Here, $X$ and $Y$ are the Cartesian coordinates along longitude and latitude, respectively; $U$ and $V$ are the corresponding currents; $z$ is the vertical coordinate; $w$ is the vertical velocity, and $n$ is the time step. In the computation, we use the three-dimensional velocity $(U, V, w)$ to track the tracers, and we set the time step $(\Delta t)$ as $3600 \mathrm{~s}$. The tracers are set along the CR on 15 May 2012 and then backward integrated to 1 January 2010.

\section{Results}

\subsection{Background environment}

The time period of the shipboard survey starts from 6 May 2012 and ends on 1 June 2012 (Table 1). Figure 2ac show the monthly mean surface wind, SST, and SSH, respectively. In this specific month, the summer monsoon has started but is not very strong (Fig. 2a). The along-coast wind prevails in the regional wind field, and the wind speed in the region far from the western coast is weaker. Positive wind curl along the Somali coast and Yemen induces coastal upwelling, which brings lower-layer cold water upward and cools the sea surface (Fig. 2b). The patterns of wind curl are roughly consistent with that of the climatological monthly mean wind stress curl (Beal et al., 2013). Otherwise, the wind curl in the NWIO is negative, which is consistent with the annual mean and forces downwelling. The basin-scale semicircular SST contour $\left(30^{\circ} \mathrm{C}\right)$ then outlines a warm area in the oceanic interior. The main part of the $\mathrm{CR}$ is located in this strikingly warm region (Fig. 2b).

On the other hand, SSH (or absolute dynamic height) shows multiple mesoscale eddies (Fig. 2c). There are some warm-core eddies (anti-cyclonic eddies), to the east of the CR (WCE1), east of the Horn of Africa (WCE2), and northeast of the Horn of Africa but very close to Yemen (WCE3). Two cold-core eddies (cyclonic eddies; CCE1 and CCE2) are also observed at either end of the CR. Besides, a remarkable westward current is observed at the latitude of $6^{\circ} \mathrm{N}$, which is noted here as a WPPW. A WPPW is pronounced compared with the circumstances around the specific region with respect to its zonal extent (7.5 $5^{\circ}$ in longitude), while the meridional extent is relatively narrow $\left(1.3^{\circ}\right.$ in latitude). The magnitude of zonal current is $0.38 \mathrm{~m} \mathrm{~s}^{-1}$. Furthermore, we investigated the longitude-time plot of the surface zonal current at $6^{\circ} \mathrm{N}$ latitude (Subrahmanyam et al., 2001, surface geostrophic current from SSH; results are not shown here); the WPPW is observed to start at $69^{\circ} \mathrm{E}$ on day 102 , and the surface current propagates westward with a phase speed of $0.2 \mathrm{~m} \mathrm{~s}^{-1}$ and arrives at $60^{\circ} \mathrm{E}$ on day 155 .

\subsection{Temperature, salinity, and density}

First, we impose the water mass analysis on the objectiveanalysis data (Sect. 2.2), and the results are shown in Fig. 3. The data support that the upper water is more saline than the Indian Equatorial Water and fresher than the Arabian Sea Water. The observed waters are likely to be mixed Indian Equatorial Water and Arabian Sea Water. When the latitude spans from the equatorial band $\left(2.3-5^{\circ} \mathrm{N}\right.$ in the present study) to the tropical band $\left(5-9.7^{\circ} \mathrm{N}\right.$ in the present study), the salinity generally increases, consistent with the northernside Arabian Sea Water being much more saline than the southern-side Indian Equatorial Water (Han et al., 2014), and this meridional variation in salinity is due to the different proportions of Indian Equatorial Water and Arabian Sea Water. On the northwest side, water columns contain ASHSW, which are observed as saline water at a potential density of approximately $24 \mathrm{~kg} \mathrm{~m}^{-3}$ (Kumar and Prasad, 1999).

The intermediate waters from our data are projected as PGW (Prasad et al., 2001) and RSW (Beal et al., 2000; Talley et al., 2011). According to Kumar and Prasad (1999), the definition of PGW (RSW) is a density range of 26.2$26.8 \mathrm{~kg} \mathrm{~m}^{-3}\left(27.0-27.4 \mathrm{~kg} \mathrm{~m}^{-3}\right)$, temperature range of $13-$ $19^{\circ} \mathrm{C}\left(9-11^{\circ} \mathrm{C}\right)$, and salinity range of $35.1-37.9$ psu (35.1$35.7 \mathrm{psu})$. 

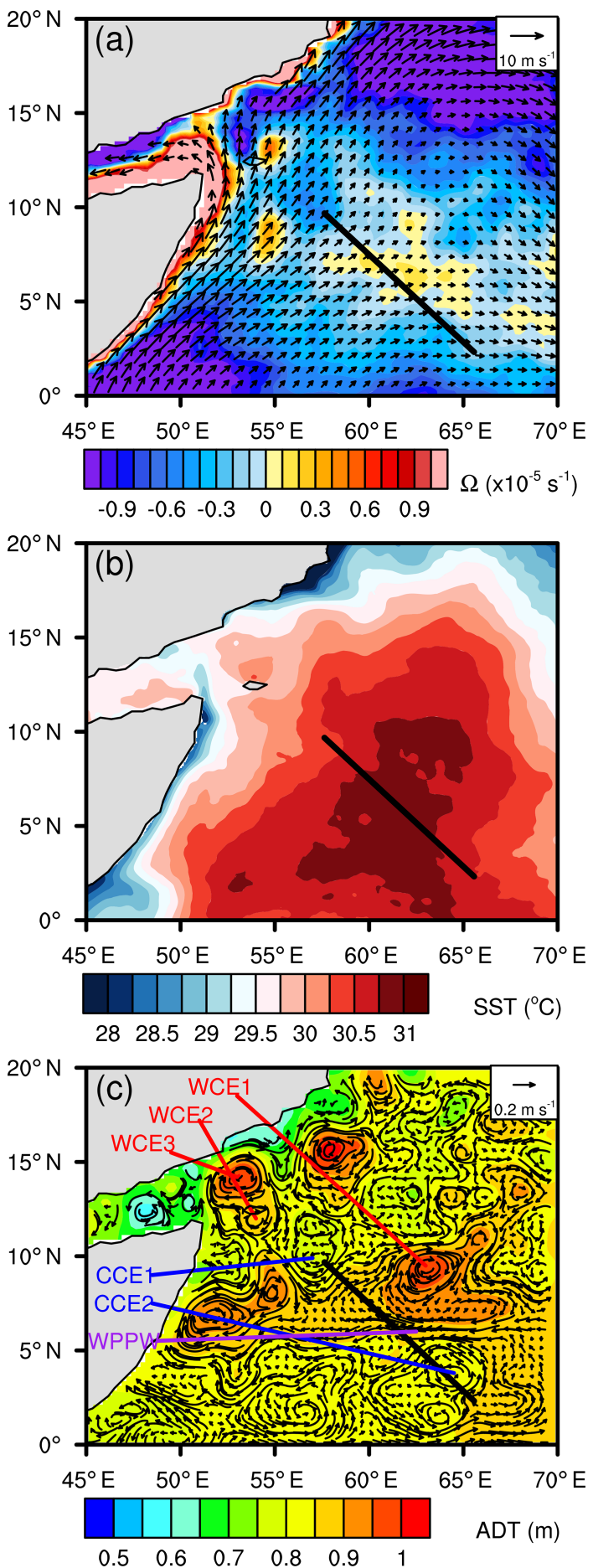

Figure 2. (a) Monthly mean wind vector and vorticity $(\Omega)$ from CCMP wind data; data are plotted every three points for wind vector; (b) monthly mean sea surface temperature from OSTIA data; and (c) monthly mean sea surface height (absolute dynamic topography) and the corresponding surface geostrophic current (shown with every two points) from AVISO. The month of May 2012 is considered.

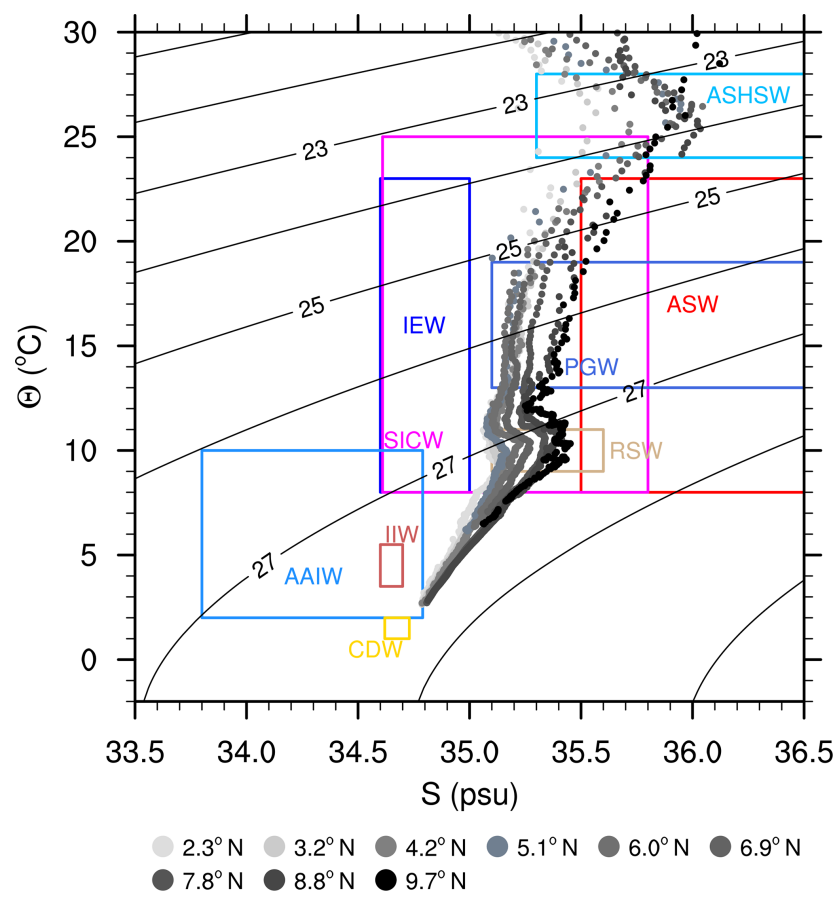

Figure 3. T-S diagram for the upper $2000 \mathrm{~m}$ of water on the CR. The water masses are defined in Emery (2001) and include the Arabian Sea Water (ASW), Indian Equatorial Water (IEW), South Indian Central Water (SICW), Antarctic Intermediate Water (AAIW), Indonesian Intermediate Water (IIW), and Circumpolar Deep Water (CDW). The rectangles represent the appropriate temperature and salinity ranges (Table 1 in Emery, 2001). Red Sea Water (RSW), Persian Gulf Water (PGW), and Arabian Sea High-Salinity Water (ASHSW) are also represented according to Kumar and Prasad (1999).

Sectional profiles of temperature and salinity are shown in Fig. 4. The thermocline is in the depth range of 100 to $150 \mathrm{~m}$ $\left(20^{\circ} \mathrm{C}\right.$ isothermal line; Xie et al., 2002). From the present observation, the thermocline is nearly flat at the equatorial band and deepens northward in the tropical band. This phenomenon is also supported by the climatological data, which reveal that the sectional distribution of the thermocline is similar to a long-standing geostrophic balanced signal. In the near surface, the isothermal line of $30^{\circ} \mathrm{C}$ rises to the surface on the northern side, suggesting a ventilation structure such that subsurface water can take part in the air-sea interaction. Meanwhile, for the intermediate water, the isothermal line tilts deeper from south to north.

The striking feature of the salinity field is that a salinity tongue appears at $100 \mathrm{~m}$ depth, where the salty water is ASHSW (Kumar and Prasad, 1999). Climatological data show that these salty waters originate from the north side and extend southward; however, in our survey, the extent is greater. We emphasize the iso-salinity line of $35.8 \mathrm{psu}$; the southern extent can reach $y=150 \mathrm{~km}\left(\right.$ or $\left.6.9^{\circ} \mathrm{N}\right)$ in climatology but $-250 \mathrm{~km}\left(\right.$ or $4.4^{\circ} \mathrm{N}$ ) in our survey. This result means 

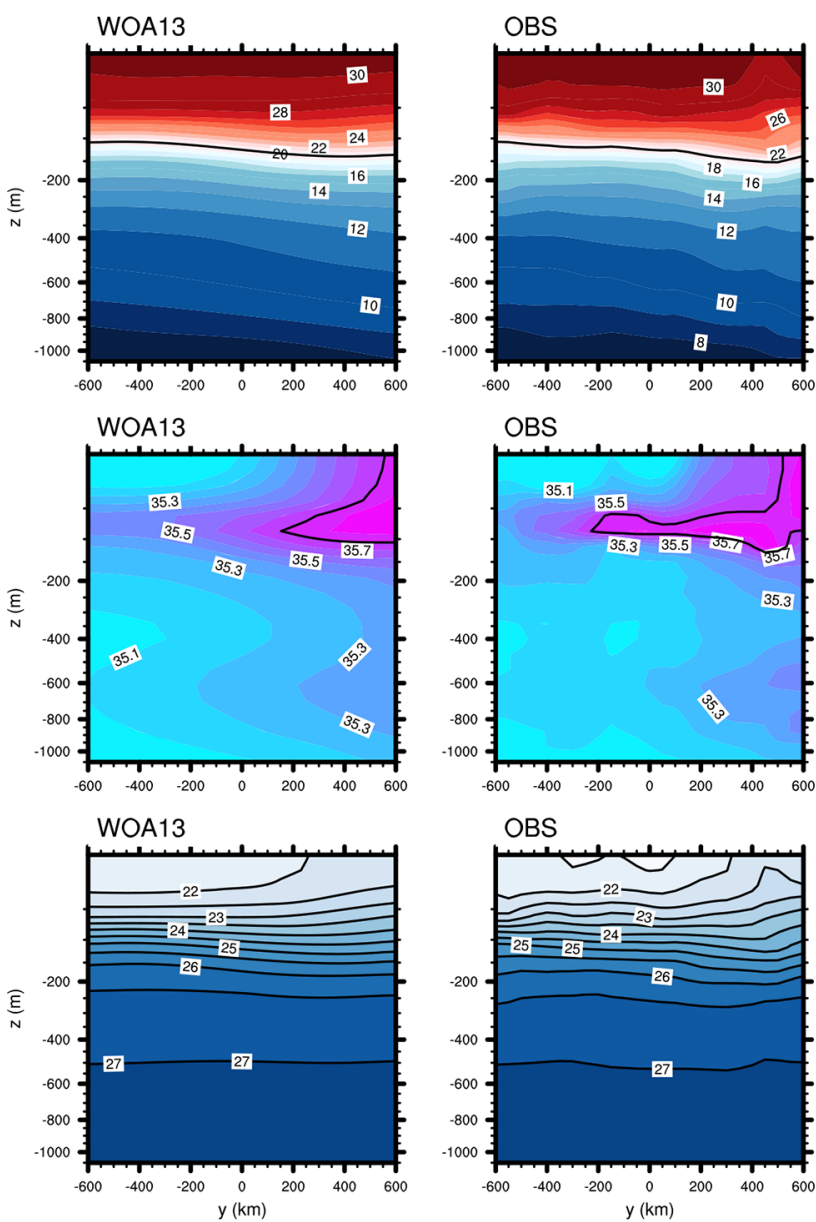

$2.32^{\circ} 3.55^{\circ} 4.77^{\circ} 6.00^{\circ} 7.23^{\circ} 8.45^{\circ} 9.68^{\circ}$

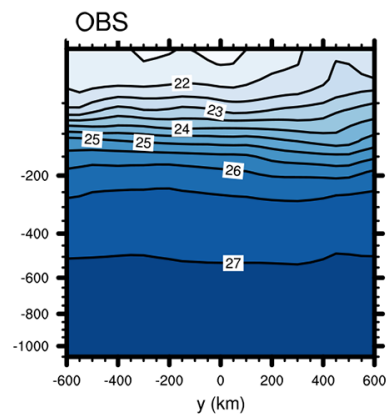

$2.32^{\circ} 3.55^{\circ} 4.77^{\circ} 6.00^{\circ} 7.23^{\circ} 8.45^{\circ} 9.68^{\circ}$ Latitude $\left({ }^{\circ} \mathrm{N}\right)$
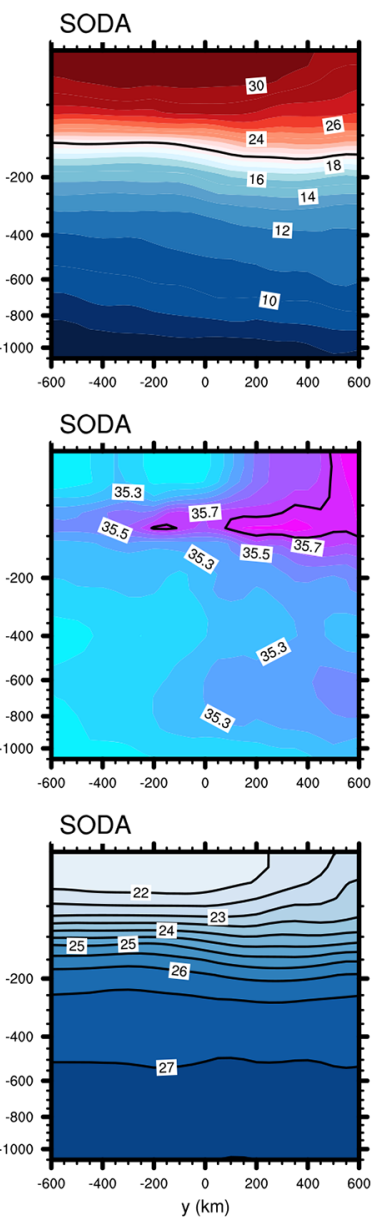

$2.32^{\circ} 3.55^{\circ} 4.77^{\circ} 6.00^{\circ} 7.23^{\circ} 8.45^{\circ} 9.68^{\circ}$ Latitude $\left({ }^{\circ} \mathrm{N}\right)$
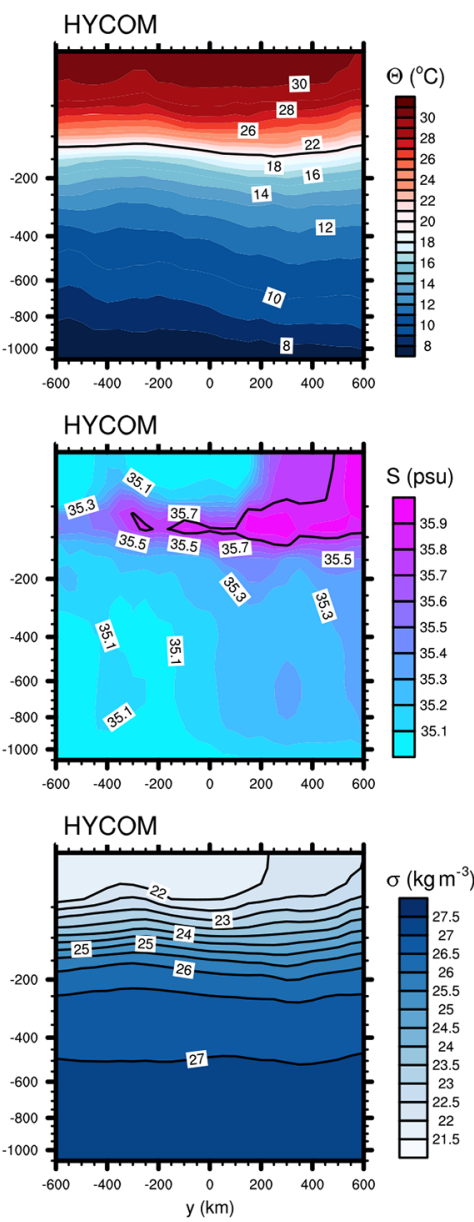

$2.32^{\circ} 3.55^{\circ} 4.77^{\circ} 6.00^{\circ} 7.23^{\circ} 8.45^{\circ} 9.68^{\circ}$ Latitude $\left({ }^{\circ} \mathrm{N}\right)$

Figure 4. Sectional profiles of potential temperature (upper panels), salinity (middle panels), and potential density (lower panels). The data sources cover the World Ocean Atlas 2013 climatology (WOA13, version 2.0/A5B2, climatological monthly mean of May), the present observations, and two reanalysis datasets, SODA and HYCOM (monthly mean of May 2012). The isothermal lines of $20^{\circ} \mathrm{C}$ are highlighted in the potential temperatures, and the iso-salinity lines of $35.8 \mathrm{psu}$ are highlighted in the salinity fields.

that the salty water extends southward more than $2.5^{\circ}$ in latitude in excess of climatology. The present sectional observation also shows the salty intermediate water as PGW and RSW (Fig. 3). The observation shows slightly more saline water than climatology on the northern side, although the overall structure is mostly consistent with the climatology. In other words, the comparison implies that the year 2012 is an anomaly year for the distributions of ASHSW, PGW, and RSW.

In the potential density field, the appearance of the $22 \mathrm{~kg} \mathrm{~m}^{-3}$ isopycnal is evident in both the snapshot and climatology. For the snapshot, the outcrop point of the $22 \mathrm{~kg} \mathrm{~m}^{-3}$ isopycnal is $y=300 \mathrm{~km}$, or $7.8^{\circ} \mathrm{N}$. It is worth noting that the outcrop point is near the transition point for signs of wind vorticity (Fig. 2a), and the results suggest that the ventilation is induced by surface wind. The north side of the outcrop point has negative wind vorticity, which promotes downward movement. Ventilation is highly related to the sinking of high-salinity water and its southern extent (Luyten et al., 1983; Kumar and Prasad, 1999).

Figure 4 also shows the reanalysis data, and essentially, the reanalysis captures the thermal structure quite well compared with the present observations and climatology. For instance, in the upper ocean, the surface warm water is distributed on the south side and northward to $y=400 \mathrm{~km}$ where the isothermal line of $30^{\circ} \mathrm{C}$ outcrops. The observed descending thermocline near $y=100 \mathrm{~km}$ is recognizable in SODA and HYCOM. It is also noted that the equatorial near-surface upwelling in HYCOM has some evidence from the present observations. For the intermediate-depth water, in SODA and HYCOM, the isothermal lines also tilt deeper from south to north, which resembles both the present observations and the climatology. 
For salinity, the southward extent of ASHSW is also captured by SODA and HYCOM, and the southward extent in HYCOM approaches the observations more closely. In the intermediate-depth water, the southward extent from the north side in SODA is similar to the observations, while the corresponding signal in HYCOM is obscured.

The upper ocean density fields from SODA and HYCOM also show clear ventilation structures and that the south-side subsurface layers are exposed to the surface on the north side. From the observations, equatorial waters with a potential density of $22 \mathrm{~kg} \mathrm{~m}^{-3}$ at a depth of $30 \mathrm{~m}$ are rising to the surface. The outcrop points of potential density of $22 \mathrm{~kg} \mathrm{~m}^{-3}$ in SODA and HYCOM are shifted southward compared with the observations. Additionally, the near-surface upwelling in the equatorial band in HYCOM is strong but not significant in the observations.

\subsection{Cross-track current}

The observation-based absolute geostrophic current is deduced from the in situ density field by thermal wind theory (Fig. 5), where the velocity is integrated downward from the surface geostrophic current (Lagerloef et al., 1999). The velocity field is relatively strong in the upper ocean, where the current field is dominated by mesoscale eddies. The crosstrack current in the equatorial band is induced by CCE2. The structure of CCE2 is asymmetric, and the positive cross-track flow is stronger than the negative counterpart. In contrast, the northwest end of the $\mathrm{CR}$ is identified as the southern part of CCE1 (northeastward flow). At $6^{\circ} \mathrm{N}$ latitude, the vertical structure of a WPPW is represented in Fig. 5a. The WPPW seems to extend vertically to a depth of $200 \mathrm{~m}$, and the horizontal extent is near $200 \mathrm{~km}$ for the current greater than $0.02 \mathrm{~m} \mathrm{~s}^{-1}$. Meanwhile, the maximum cross-track current of the WPPW is $0.12 \mathrm{~m} \mathrm{~s}^{-1}$. The current field also captures the northeastward current (less than $0.075 \mathrm{~m} \mathrm{~s}^{-1}$ ) in the intermediate depth $(-200 \leq y \leq-20 \mathrm{~km}$ and $150 \leq y \leq 350 \mathrm{~km})$, which is due to the corresponding isothermal tilting (Fig. 4).

For the reanalysis data, as shown in Fig. 5, although the surface currents are similar due to the assimilation of SSH in the reanalysis process, the cross-track current from reanalysis is quite different from the observation-based absolute geostrophic current. The differences are observed in three aspects. First, the mesoscale eddy CCE2 is not well represented for the vertical structure, as SODA and HYCOM limit the southern part of CCE2 to the upper $200 \mathrm{~m}$, where the current speed is faster than $0.05 \mathrm{~m} \mathrm{~s}^{-1}$. Meanwhile, in SODA and HYCOM, the northern part of the mesoscale eddy (CCE2) has much latitude expansion and merges with the WPPW. Second, the undercurrent in the southern portion of the observations differs from those in SODA and HYCOM. The undercurrent in SODA is relatively weak, while HYCOM shows a northward shift of the current core. Finally, for the northern portion, SODA gives a relatively shallow depth for the surface northeastward current, and the corresponding horizontal extent exceeds that of the observations. The locations of surface zero current in SODA and observation are $y=170$ and $240 \mathrm{~km}$, respectively.

Part of the difference between observation-based absolute geostrophic current and reanalysis current is probably due to the near-surface Ekman current. The mean surface Ekman speed, which is approximately the difference between surface geostrophic current and in situ surface current (from surface drifter), is within $0.1 \mathrm{~m} \mathrm{~s}^{-1}$ in the northern Indian Ocean (Saj, 2017). Besides, the climatological monthly mean mixed-layer depth in May is roughly $20 \mathrm{~m}$ at station $9.5^{\circ} \mathrm{N}$ and $59.5^{\circ} \mathrm{E}$ (on the CR; Liu et al., 2018). Considering the near-surface Ekman current decays exponentially with depth, the near-surface Ekman currents in reanalysis datasets are, therefore, relatively weak to affect the main results as mentioned above.

\subsection{Tracers}

According to the ventilation theory, if the wind at the north boundary of the NWIO was eastward and the ocean density field had ventilation structure, then the flow over the CR was southwestward, and the waters over the CR moved from northeast side. Here, the SODA reanalysis supplies compact datasets for passive tracers; therefore, we set some passive tracers along the $\mathrm{CR}$ and backtrack their trajectories using the Lagrangian description (Sect. 2.5), and the results are shown in Fig. 6. In order to better describe the trajectories, we separate the CR to three latitude bands as 8-9.8, 5-8, and 2.3$5^{\circ} \mathrm{N}$ (equatorial band). For ASHSW, we set the tracers at a depth of $100 \mathrm{~m}$, and the trajectories reveal different pathways on the CR. In the latitude band of $8-9.8^{\circ} \mathrm{N}$ (Fig. 6a), the trajectories emphasize the north branch of the East African Coastal Current during summer monsoon (Schott and McCreary, 2001; Schott et al., 2009); meanwhile, the water at the north station of the CR comes from the northeast side, and one station water measurement shows the cross-equatorial current around $53^{\circ} \mathrm{E}$ (east of Southern Gyre; Schott et al., 2009). For latitudes from 5 to $8^{\circ} \mathrm{N}$ (Fig. 6c), the water mainly originates from the northeast side, and the trajectories resemble those of the ventilation theory (Luyten et al., 1983; Qiu and Huang, 1995). The results show water coming mainly from the Arabian Basin and the southwestward flow brings ASHSW onto the CR. On some occasions, the $100 \mathrm{~m}$ depth waters in this latitude section are from the Equator, and the pathways show the north branch of the East African Coastal Current and the cross-equatorial current around $66^{\circ} \mathrm{E}$, respectively. Similarly, the pathways starting east of the Horn of Africa are probably due to the off-coast current north of the Great Whirl or mesoscale eddies (Chelton et al., 2011; Wang et al., 2019). In the equatorial band (Fig. 6e), the nearEquator tracers come from the west side, which is consistent with the north branch of the East African Coastal Current. Meanwhile, for the relatively north-side tracers in the equatorial band, the trajectories backtrack to the east side, which is 

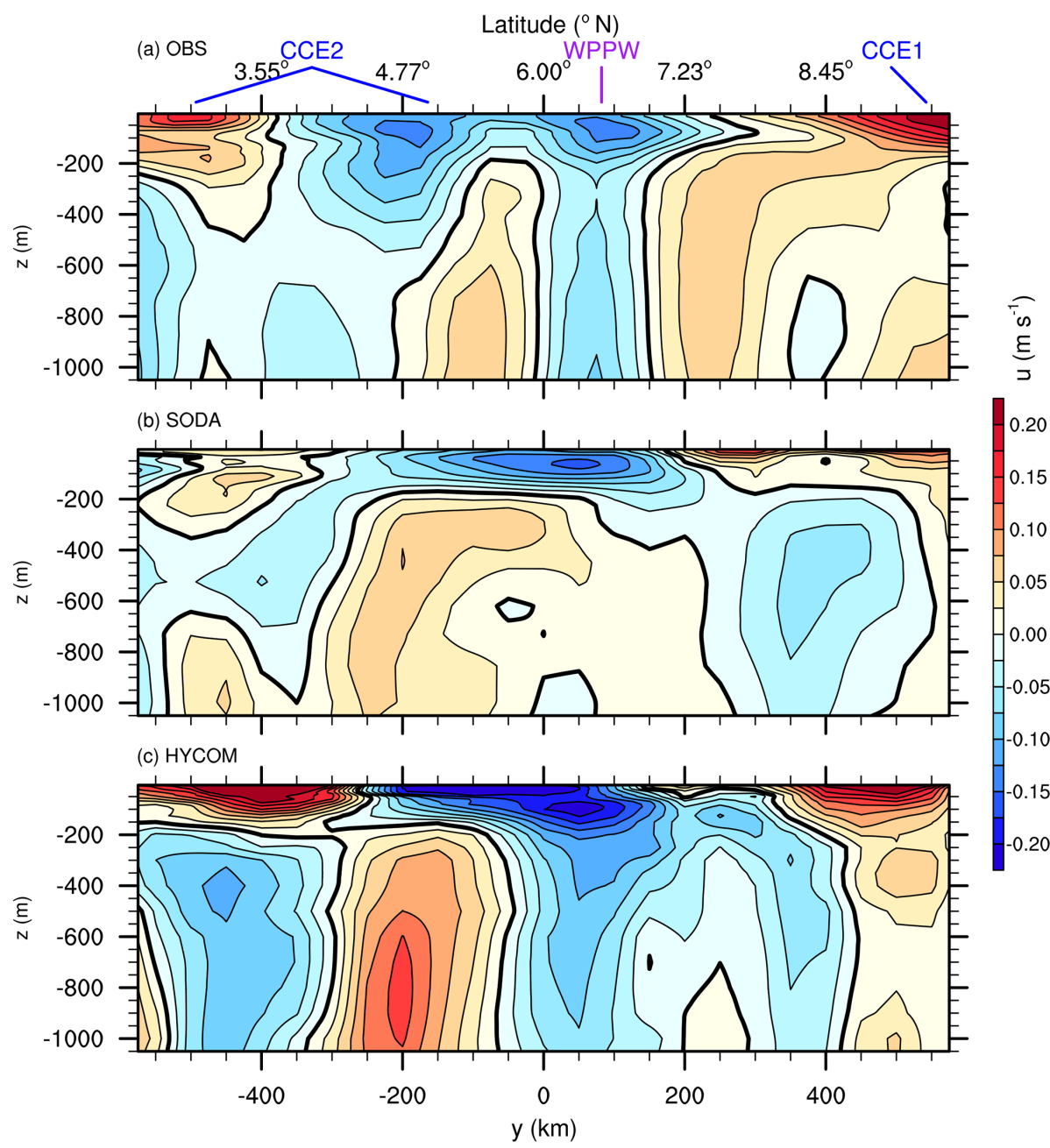

Figure 5. Sectional cross-track current: (a) absolute geostrophic current; panels (b) and (c) show currents in SODA and HYCOM reanalyses, respectively. Northeastward current is positive. Thick black lines are the zero contours.

probably following a westward mean flow, mesoscale eddy, or WPPW.

For RSW in the intermediate-depth layer at $700 \mathrm{~m}$, the trajectories show the zonal movement in the $8-9.8^{\circ} \mathrm{N}$ band (Fig. 6b). Two trajectories move from the west side, in accordance with the potential vorticity explanation (Beal et al., 2000), which RSW moves southward along the coast with the help of winter monsoon, and then it leaves the coast and shifts to middle ocean via zonal movement. Meanwhile, there are pathways directly from the northwest, and these trajectories support the idea that $700 \mathrm{~m}$ waters are probably directly from east of the Horn of Africa (or Gulf of Aden) without southward movements along the coast (Shapiro and Meschanov, 1991). In the $5-8^{\circ} \mathrm{N}$ band (Fig. 6d), the mainly eastward zonal movements agree with Beal et al. (2000); meanwhile, some westward trajectories resemble the prediction of ventilation theory (Luyten et al., 1983; Qiu and Huang, 1995). At last, in the equatorial band (Fig. 6f), most trajectories show eastward zonal movement. Other two tra- jectories follow westward zonal movement, and one extra trajectory moves from the northwest with a circular track. Hence, these trajectories display three kinds of pathways.

\section{Discussion}

The CTD and XCTD data are useful in reconstructing the three-dimensional oceanic data. Based on theoretical model, three-dimensional ocean interior fields can be derived using surface information (SSH and sea surface density), but a reliable mean density field is required (Lapeyre and Klein, 2006; Wang et al., 2013; Liu et al., 2014; Yan et al., 2020). In other words, for operational purposes, the mesoscale eddy coherent structure could be built on a known background density field. The Argo-only data are not sufficient to describe the mesoscale eddy in the NWIO, and they could not supply sufficient background density. In the present study, the maximum distance between Argo profiles is $500 \mathrm{~km}$ along the CR; 
(a) $z=100 \mathrm{~m}$

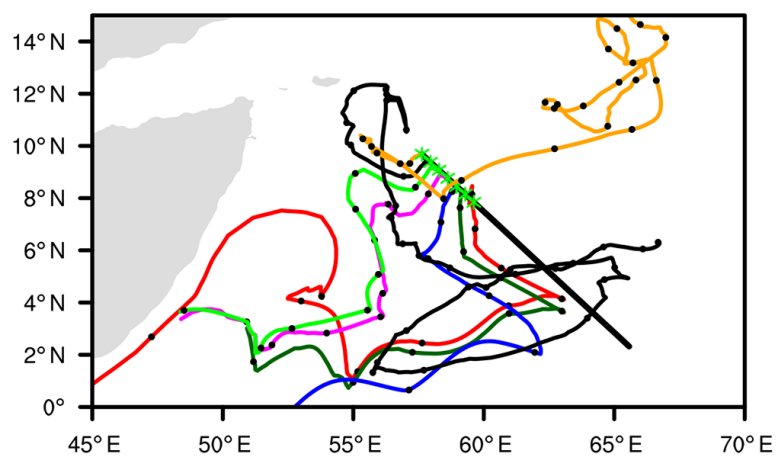

(c) $z=100 \mathrm{~m}$

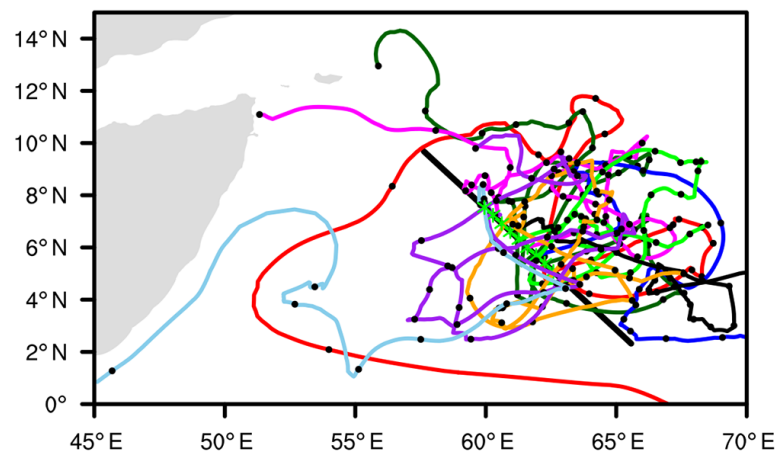

(e) $z=100 \mathrm{~m}$

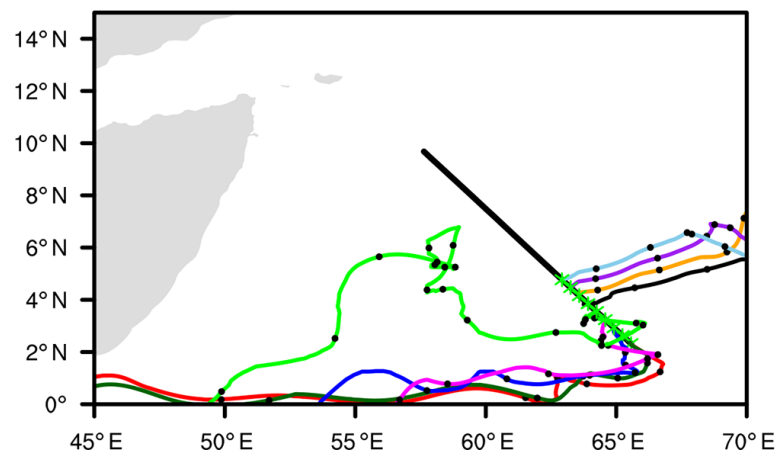

(b) $z=700 \mathrm{~m}$

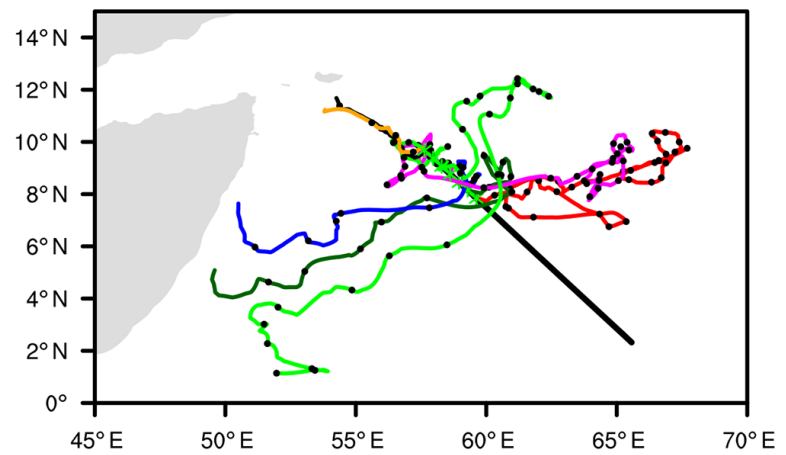

(d) $z=700 \mathrm{~m}$

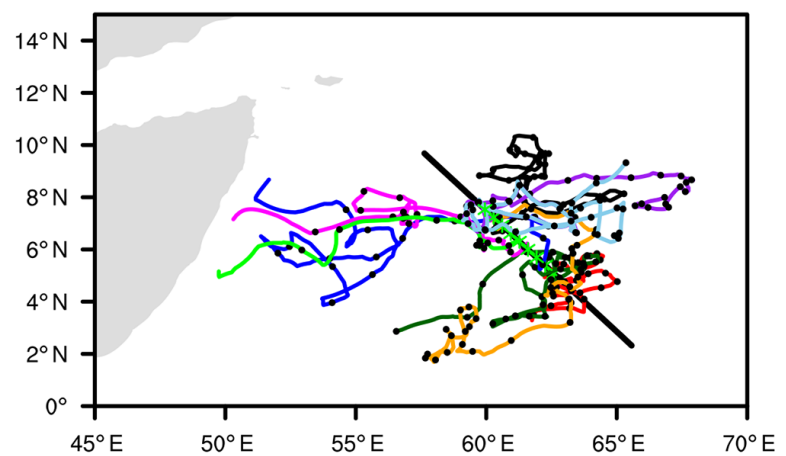

(f) $\mathrm{z}=700 \mathrm{~m}$

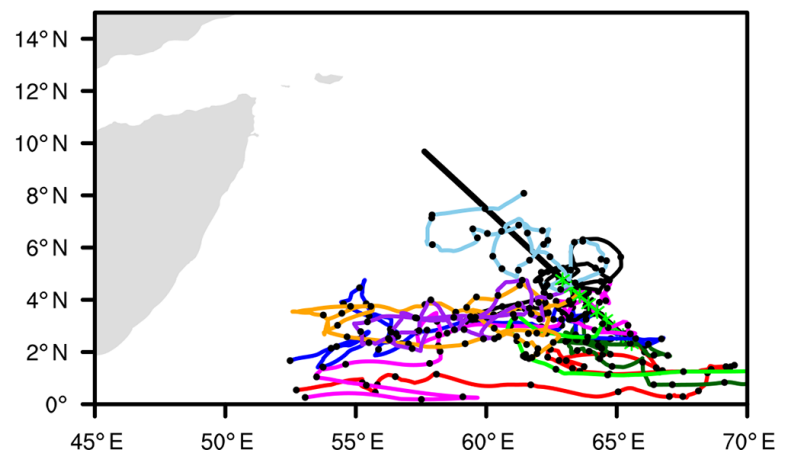

Figure 6. Passive tracers using SODA reanalysis. The Carlsberg Ridge is presented by black line. The tracers at 15 May 2012 are shown as green asterisks (ending points). The tracers are backtracked to 1 January 2010. The time interval is 1 month, as denoted by the black dots. (a, b) $8-9.8^{\circ} \mathrm{N} ;(\mathbf{c}, \mathbf{d}) 5-8^{\circ} \mathrm{N} ;(\mathbf{e}, \mathbf{f}) 2-5^{\circ} \mathrm{N}$.

however, after adding the shipboard station data, the maximum distance decreases to $100 \mathrm{~km}$, which falls into the eddypermitting scale. Sufficient sampling produces more reliable vertical structures of temperature, salinity, and density.

The most remarkable signal in the upper ocean is the southward extent of ASHSW, where the counterpart in the climatology data exists but is weak in the horizontal extent. It is surprising that the HYCOM reanalysis captures the phenomenon well, while SODA shows some disadvantages. Although both SODA and HYCOM assimilate the Argo data into oceanic general circulation models (OGCMs), the assimilation methods of SODA and HYCOM are considerably different. SODA adopts optimal interpolation (Carton et al., 2018), while HYCOM uses a three-dimensional variational scheme. One advantage of a three-dimensional variational scheme versus optimal interpolation is the conservation of dynamical constraints (Zhu et al., 2006; Yin et al., 2012; Edwards et al., 2015). Therefore, HYCOM probably describes better the wind-driven circulations, monsoon-induced coastal current, and mesoscale eddy movement, which are all related to the southward extent of ASHSW. In the comparative analysis, the state-of-the-art reanalysis is still insufficient to provide good current data. Although similar sea surface dynamic heights are taken into account, the incorrect density 
field leads to a false vertical structure. It is also noted that the bias is probably further amplified in OGCM and leads to potential unrealistic simulations if these reanalysis data are used in the model for initialization and boundary forcing.

The present study uses SODA reanalysis to investigate the origins of water particles over the CR. However, the corresponding results need further validation. For instance, the present study reveals that both the mesoscale eddy and WPPW are misinterpreted by SODA; therefore, the waters trapped in the mesoscale eddy and WPPW probably move in wrong ways. Meanwhile, trajectories from different oceanic reanalyses differ as follows: the southward extents of ASHSW are not the same in SODA and HYCOM.

From the theoretical viewpoint, the phase speed of first, second-, and third-mode baroclinic Rossby waves at $6^{\circ} \mathrm{N}$ in the Indian Ocean is roughly $0.6,0.2 \mathrm{~s}$, and $0.1 \mathrm{~m} \mathrm{~s}^{-1}$, respectively (Subrahmanyam et al., 2001). The phase speed of the WPPW matches well with that of the second-mode baroclinic Rossby wave. For the generation mechanism, Subrahmanyam et al. (2001) argued that this kind of Rossby wave was probably radiated from a coastal trapped Kelvin wave at the southwestern coast of India. Meanwhile, this kind of Rossby wave can bring wave energy from the southwestern coast of India to the Somali coast and feed the Somali Current and Somali eddies. The present study displays the vertical structure of this kind of Rossby wave; however, the dynamics of the WPPW (and Rossby wave) and its association with the Somali Current and Somali eddies call for further study.

Generally, the hydrothermal plume in the CR uplifts from the sea bottom to a water depth of $2500 \mathrm{~m}$ (Murton et al., 2006; Wang et al., 2017). The present paper restricts the sectional current study to the upper $1050 \mathrm{~m}$ (Figs. 4-5). Within this depth, the water is easily affected by surface forcing. However, on the basin-scale, wind-driven circulation, the surface wind forcing affects deeper ocean through quasigeostrophic instability (Rhines and Young, 1982) and meridional overturning circulation. Meanwhile, the upper $1050 \mathrm{~m}$ dynamics over the $\mathrm{CR}$ is related to the cross-ridge water transport in upper ocean, which influences the deep ocean circulation through pressure adjustment. Therefore, the results provide potential use in future studies of hydrothermal plumes.

\section{Conclusions}

This paper reports a onetime hydrographic survey on the CR in the NWIO, where the latitudes cover the equatorial (2.3$\left.5^{\circ} \mathrm{N}\right)$ and tropical $\left(5-9.6^{\circ} \mathrm{N}\right)$ bands. The station CTD/XCTD sampling and the Argo floats build the sectional structures of temperature and salinity as well as density. The striking feature is the southern extent of ASHSW from northwest of the CR in the upper ocean. Meanwhile, the temperature and density fields display clear ventilation structures. In the inter- mediate depth, the observations also capture RSW at a depth near $700 \mathrm{~m}$.

Furthermore, we compute the absolute geostrophic current based on the density profiles and sea surface height. The vertical structure of the cross-track current reveals strong signals of mesoscale eddies in the upper ocean and a relatively weak northeastward current in the intermediate depth. We also identify a strong westward-propagating planetary wave at a latitude of $6^{\circ} \mathrm{N}$. The longitude and latitude lengths are 7.5 and $1.3^{\circ}$, respectively. The corresponding phase speed is $0.2 \mathrm{~m} \mathrm{~s}^{-1}$, and the vertically affected depth is roughly $200 \mathrm{~m}$.

We further evaluate the state-of-the-art reanalysis with the present observations. As a result, because the Argo profiles and satellite SSH are assimilated into the reanalysis datasets, HYCOM and SODA show relatively good qualities for temperature, salinity, and density. However, the reanalysis crosstrack currents show large discrepancies compared with the absolute geostrophic current. Most importantly, HYCOM and SODA misinterpret some mesoscale eddies in the current field. Over the NWIO, the mesoscale eddies are relatively important but cannot be well described by the Argo-only data source. The present analysis shows more data sources for a potential data assimilation experiment. The present situation of insufficient sampling prompts more research activity in the NWIO.

To explore the pathways of ASHSW and RSW during the expedition time, we set tracers in the SODA dataset at depths of 100 and $700 \mathrm{~m}$ and backtrack their trajectories via the three-dimensional Lagrangian description. Overall, for the $100 \mathrm{~m}$ depth waters, the results reveal the pathways related to the northern branch of the East African Coastal Current and the flow from the northeast side (or Arabian Basin), while for the $700 \mathrm{~m}$ depth waters, the trajectories mainly follow the zonal direction from either the west or east side. The results give direct-viewing descriptions and call for further dynamical investigations.

Data availability. OSTIA SST data were produced by the GHRSST project (http://ghrsst-pp.metoffice.com/pages/latest_ analysis/index.htm, GHRSST project, 2017). WOA data were available at https://www.nodc.noaa.gov/ (NODC, 2017). Daily Argo float data were downloaded from http://www.argodatamgt.org (Argo group, 2017). CCMP wind data were provided by Remote Sensing Systems (http://www.remss.com/measurements/ccmp, Wentz et al., 2015). AVISO SSH data were accessed under http://www.aviso.altimetry.fr (SSALTO/DUACS, 2017). SODA data were obtained from https://www.atmos.umd.edu/ ocean/ (SODA Project, 2017), and HYCOM data were downloaded from https://www.hycom.org/data/glbu0pt08/expt-19pt1 (HYCOM Project, 2017). Shipboard data are available upon reasonable request to the corresponding authors.

Author contributions. $\mathrm{HH}, \mathrm{YuW}$, and $\mathrm{XH}$ conceived the idea. $\mathrm{XH}$, $\mathrm{ZQ}$, and YeW conducted the in situ survey. HH collected publicly 
distributed data and performed the data analysis. HH, YuW, YaW, and PL interpreted the results. $\mathrm{HH}$ and $\mathrm{XH}$ prepared the paper with contributions from all co-authors.

Competing interests. The authors declare that they have no conflict of interest.

Acknowledgements. We are thankful to editor and two anonymous reviewers for their constructive suggestions and comments.

Financial support. This research has been supported by the China Ocean Mineral Resources R\&D Association Project (grant nos. DY135-S2-1 and DY135-E2-1-01), the Strategic Priority Research Program of the Chinese Academy of Sciences (grant no. XDA20060501), and the National Natural Science Foundation of China (grant nos. 41730535, 91951201, and 41621064).

Review statement. This paper was edited by John M. Huthnance and reviewed by two anonymous referees.

\section{References}

Argo group: Argo float vertical profile, available at: http://www. argodatamgt.org, last access: 16 April 2017.

Atlas, R., Hoffman, R. N., Ardizzone, J., Leidner, S. M., Jusem, J. C., Smith, D. K., and Gombos, D.: A cross-calibrated, multiplatform ocean surface wind velocity product for meteorological and oceanographic applications, B. Am. Meteorol. Soc., 92, 157174, 2011.

Barnes, S. L.: Applications of the Barnes Objective Analysis Scheme. Part I: Effects of undersampling, wave position, and station randomness, J. Atmos. Ocean. Tech., 11, 1433-1448, 1994.

Beal, L. M., Ffield, A., and Gordon, A. L.: Spreading of Red Sea overflow waters in the Indian Ocean, J. Geophys. Res.-Oceans, 105, 8549-8564, 2000.

Beal, L. M., Hormann, V., Lumpkin, R., and Foltz, G. R.: The response of the surface circulation of the Arabian Sea to monsoonal forcing, J. Phys. Oceanogr., 43, 2008-2022, 2013.

Bower, A. S., Hunt, H. D., and Price, J. F.: Character and dynamics of the Red Sea and Persian Gulf outflows, J. Geophys. Res.-Oceans, 105, 6387-6414, https://doi.org/10.1029/1999JC900297, 2000.

Carton, J. A. and Giese, B. S.: A reanalysis of ocean climate using Simple Ocean Data Assimilation (SODA), Mon. Weather Rev., 136, 2999-3017, 2008.

Carton, J. A., Chepurin, G. A., and Chen, L. G.: SODA3: A new ocean climate reanalysis, J. Climate, 31, 6967-6983, 2018.

Chelton, D. B. and Schlax, M. G.: Global observations of oceanic Rossby waves, Science, 272, 234-238, 1996.

Chelton, D. B., Schlax, M. G., and Samelson, R. M.: Global observations of nonlinear mesoscale eddies, Prog. Oceanogr., 91, 167-216, 2011.
Chen, G. X., Han, W. Q., Li, Y. L., Wang, D. X., and McPhaden, M. J.: Seasonal-to-interannual time scale dynamics of the equatorial undercurrent in the Indian Ocean, J. Phys. Oceanogr., 54, 1532$1553,2015$.

Cleveland, W. S. and Grosse, E.: Computational methods for local regression, Stat. Comput., 1, 47-62, 1991.

Donlon, C. J., Martin, M., Stark, J., Roberts-Jones, J., Fiedler, E., and Wimmer, W.: The Operational Sea Surface Temperature and Sea Ice analysis (OSTIA) system, Remote Sens. Environ., 116, 140-158, 2012.

Durgadoo, J. V., Rühs, S., Biastoch, A., and Böning, C. W. B.: Indian Ocean sources of Agulhas leakage, J. Geophys. Res.-Oceans, 122, 3481-3499, https://doi.org/10.1002/2016JC012676, 2017.

Edwards, C. A., Moore, A. M., Hoteit, I., and Cornuelle, B. D.: Regional ocean data assimilation, Annu. Rev. Mar. Sci., 7, 21 $42,2015$.

Emery, W. J.: Water Types and Water Masses, in: Encyclopedia of Ocean Sciences (Second Edition), edited by: Steele, J. H., pp. 291-299, Academic Press, Oxford, second edn., https://doi.org/10.1016/B978-012374473-9.00108-9, 2001.

GHRSST project: Analysed foundation sea surface temperature over the global ocean: A merged multi-sensor L4 Foundation SST product (OSTIA), available at: http://ghrsst-pp.metoffice. com/pages/latest_analysis/index.htm, last access: 27 June 2017.

Han, W. and McCreary Jr., J. P.: Modeling salinity distributions in the Indian Ocean, J. Geophys. Res.-Oceans, 106, 859-877, https://doi.org/10.1029/2000JC000316, 2001.

Han, W. Q., Vialard, J., McPhaden, M. J., Lee, T., Masumoto, Y., Feng, M., and De Ruijter, W. P. M.: Indian Ocean decadal variability: A review, B. Am. Meteorol. Soc., 95, 1679-1703, 2014.

HYCOM Project: HYCOM + NCODA Global 1/12 ${ }^{\circ}$ Reanalysis dataset, version GLBu0.08/expt_19.1, available at: https:// www.hycom.org/data/glbu0pt08/expt-19pt1, last access: $25 \mathrm{Au}-$ gust 2017.

Kumar, S. P. and Prasad, T. G.: Formation and spreading of Arabian Sea high-salinity water mass, J. Geophys. Res.-Oceans, 104, 1455-1464, 1999.

Lagerloef, G. S. E., Mitchum, G. T., Lukas, R. B., and Niiler, P. P.: Tropical Pacific near-surface currents estimated from altimeter, wind, and drifter data, J. Geophys. Res.-Oceans, 104, 23313 23326, 1999.

Lapeyre, G. and Klein, P.: Dynamics of the upper cceanic layers in terms of surface quasigeostrophy theory, J. Phys. Oceanogr., 36, 165-176, https://doi.org/10.1175/JPO2840.1, 2006.

Li, Y. L. and Han, W. Q.: Decadal sea level variations in the Indian Ocean investigated with HYCOM: Roles of climate modes, ocean internal variability, and stochastic wind forcing, J. Climate, 28, 9143-9165, 2015.

Liu, L., Peng, S., Wang, J., and Huang, R. X.: Retrieving density and velocity fields of the ocean's interior from surface data, J. Geophys. Res.-Oceans, 119, 8512-8529, https://doi.org/10.1002/2014JC010221, 2014.

Liu, L. L., Huang, R. X., and Wang, F.: Ventilation of a monsoondominated ocean: Subduction and obduction in the North Indian Ocean, J. Geophys. Res.-Oceans, 123, 4449-4463, 2018.

Luyten, J. L., Pedlosky, J., and Stommel, H.: The ventilated thermocline, J. Phys. Oceanogr., 13, 292-309, 1983. 
McCreary Jr., J. P.: Modeling equatorial ocean circulation, Annu. Rev. Fluid Mech., 17, 359-409, 1985.

Murton, B. J., Baker, E. T., Sands, C. M., and German, C. R.: Detection of an unusually large hydrothermal event plume above the slow-spreading Carlsberg Ridge: NW Indian Ocean, Geophys. Res. Lett., 33, L10608, https://doi.org/10.1029/2006GL026048, 2006.

NODC: World Ocean Atlas 2013, version 2, available at: https:// www.nodc.noaa.gov/, last access: 6 May 2017.

Prasad, T. G. and Ikeda, M.: A numerical study of the seasonal variability of Arabian Sea high-salinity water, J. Geophys. Res.-Oceans, 107, 3197, https://doi.org/10.1029/2001JC001139, 2002.

Prasad, T. G., Ikeda, M., and Kumar, S. P.: Seasonal spreading of the Persian Gulf Water mass in the Arabian Sea, J. Geophys. Res.Oceans, 106, 17059-17071, 2001.

Qiu, B. and Huang, R. X.: Ventilation of the North Atlantic and North Pacific: Subduction versus obduction, J. Phys. Oceanogr., 25, 2374-2390, 1995.

Rhines, P. B.: Waves and turbulence on a beta-plane, J. Fluid Mech., 69, 417-443, 1975.

Rhines, P. B. and Young, W. R.: Homogenization of potential vorticity in planetary gyres, J. Fluid Mech., 122, 347-367, 1982.

Riser, S. C., Freeland, H. J., Roemmich, D., Wijffels, S., Troisi, A., Belbéoch, M., Gilbert, D., Xu, J., Pouliquen, S., Thresher, A., Le Traon, P.-Y., Maze, G., Klein, B., Ravichandran, M., Grant, F., Poulain, P.-M., Suga, T., Lim, B., Sterl, A., Sutton, P., Mork, K.A., Vélez-Belchí, P. J., Ansorge, I., King, B., Turton, J., Baringer, M., and Jayne, S. R.: Fifteen years of ocean observations with the global Argo array, Nat. Clim. Change, 6, 145-153, 2016.

Saj, R. P.: Surface velocity estimates of the North Indian Ocean from satellite gravity and altimeter missions, Int. J. Remote Sens., 38, 296-313, 2017.

Saji, N. H., Goswami, B. N., Vinayachandran, P. N., and Yamagata, T.: A dipole mode in the tropical Indian Ocean, Nature, 401, 360363, 1999.

Schott, F. A. and McCreary Jr., J. P.: The monsoon circulation of the Indian Ocean, Prog. Oceanogr., 51, 1-123, 2001.

Schott, F. A., Xie, S. P., and McCreary Jr., J. P.: Indian Ocean circulation and climate variability, Rev. Geophys., 47, RG1002, https://doi.org/10.1029/2007RG000245, 2009.

Shapiro, G. and Meschanov, S.: Distribution and spreading of Red Sea Water and salt lens formation in the northwest Indian Ocean, Deep-Sea Res.-Pt. A, 38, 21-34, https://doi.org/10.1016/01980149(91)90052-H, 1991.

Sharma, G. S., Gouveia, A. D., and Satyendranath, S.: Incursion of the Pacific Ocean water into the Indian Ocean, Proc. Indian Acad. Sci., 87A, 29-45, 1978.

SODA Project: SODA3 ocean climate reanalysis dataset, version 3.3.1, available at: https://www.atmos.umd.edu/ ocean/, last access: 27 August 2017.

SSALTO/DUACS: Delayed-time merged all satellites Global Ocean Gridded Absolute Dynamic Topography L4 product, available at: http://www.aviso.altimetry.fr, last access: 3 March 2017.

Subrahmanyam, B., Robinson, I. S., Blundell, J. R., and Challenor, P. G.: Indian ocean Rossby waves observed in TOPEX/POSEIDON altimeter data and in model simulations, Int. J. Remote Sens., 22, 141-167, 2001.
Talley, L. D., Pickard, G. L., Emery, W. J., and Swift, J. H.: Descriptive physical oceanography: An introduction, Elsevier, Burlingham, 6 edn., 2011.

Vecchi, G. A., Xie, S. P., and Fischer, A. S.: Ocean-atmosphere covariability in the Western Arabian Sea, J. Climate, 17, 12131224, 2004.

Vitale, S. S., DiMarco, S. F., Seidel, H. F., and Wang, Z. K.: Circulation analysis in the northwest Indian Ocean using ARGO floats and surface drifter observations, and SODA reanalysis output, Dynam. Atmos. Oceans, 78, 57-70, 2017.

Wang, J., Flierl, G. R., LaCasce, J. H., McClean, J. L., and Mahadevan, A.: Reconstructing the ocean's interior from surface data, J. Phys. Oceanogr., 43, 1611-1626, https://doi.org/10.1175/JPOD-12-0204.1, 2013.

Wang, S., Zhu, W. J., Ma, J., Ji, J. L., Yang, J. S., and Dong, C. M.: Variability of the Great Whirl and its impacts on atmospheric processes, Remote Sens., 11, 322, https://doi.org/10.3390/rs11030322, 2019.

Wang, Y. J., Han, X. Q., Petersen, S., Frische, M., Qiu, Z. Y., Li, H. M., Li, H. L., Wu, Z. C., and Cui, R. Y.: Mineralogy and trace element geochemistry of sulfide minerals from the Wocan Hydrothermal Field on the slow-spreading Carlsberg Ridge Indian Ocean, Ore Geol. Rev., 84, 1-19, 2017.

Webster, P. J., Moore, A. M., Loschnigg, J. P., and Leben, R. R.: Coupled ocean-atmosphere dynamics in the Indian Ocean during 1997-98, Nature, 401, 356-360, 1999.

Wentz, F. J., Scott, J., Hoffman, R., Leidner, M., Atlas, R., and Ardizzone, J.: Remote Sensing Systems Cross-Calibrated MultiPlatform (CCMP) 6-hourly ocean vector wind analysis product on 0.25 deg grid, Version 2.0, Remote Sensing Systems, Santa Rosa, CA, available at: http://www.remss.com/measurements/ ccmp (last access: 28 June 2017), 2015.

Xie, S. P., Annamalai, H., Schott, F. A., and McCreary Jr., J. P.: Structure and mechanisms of south Indian Ocean climate variability, J. Climate, 15, 864-878, 2002.

Yan, H., Wang, H., Zhang, R., Chen, J., Bao, S., and Wang, G.: A dynamical-statistical approach to retrieve the ocean interior structure from surface data: SQGmEOF-R, J. Geophys. Res.-Oceans, 125, e2019JC015840, https://doi.org/10.1029/2019JC015840, 2020.

Yang, G., He, H. L., Wang, Y., Han, X. Q., and Wang, Y. J.: Evaluating a satellite-based sea surface temperature by shipboard survey in the Northwest Indian Ocean, Acta Oceanol. Sin., 35, 52-58, 2016.

Yin, X. Q., Qiao, F. L., Yang, Y. Z., Xia, C. S., and Chen, X. Y.: Argo data assimilation in ocean general circulation model of Northwest Pacific Ocean, Ocean Dynam., 62, 1059-1071, 2012.

You, Y.: Intermediate water circulation and ventilation of the Indian Ocean derived from water-mass contributions, J. Mar. Res., 56, 1029-1067, https://doi.org/10.1357/002224098765173455, 1998.

Zhu, J., Zhou, G. Q., Yan, C. X., Fu, W. W., and You, X. B.: A threedimensional variational ocean data assimilation system: Scheme and preliminary results, Science in China Series D: Earth Sciences, 49, 1212-1222, 2006. 